\title{
Science and Myth in Evolution
}

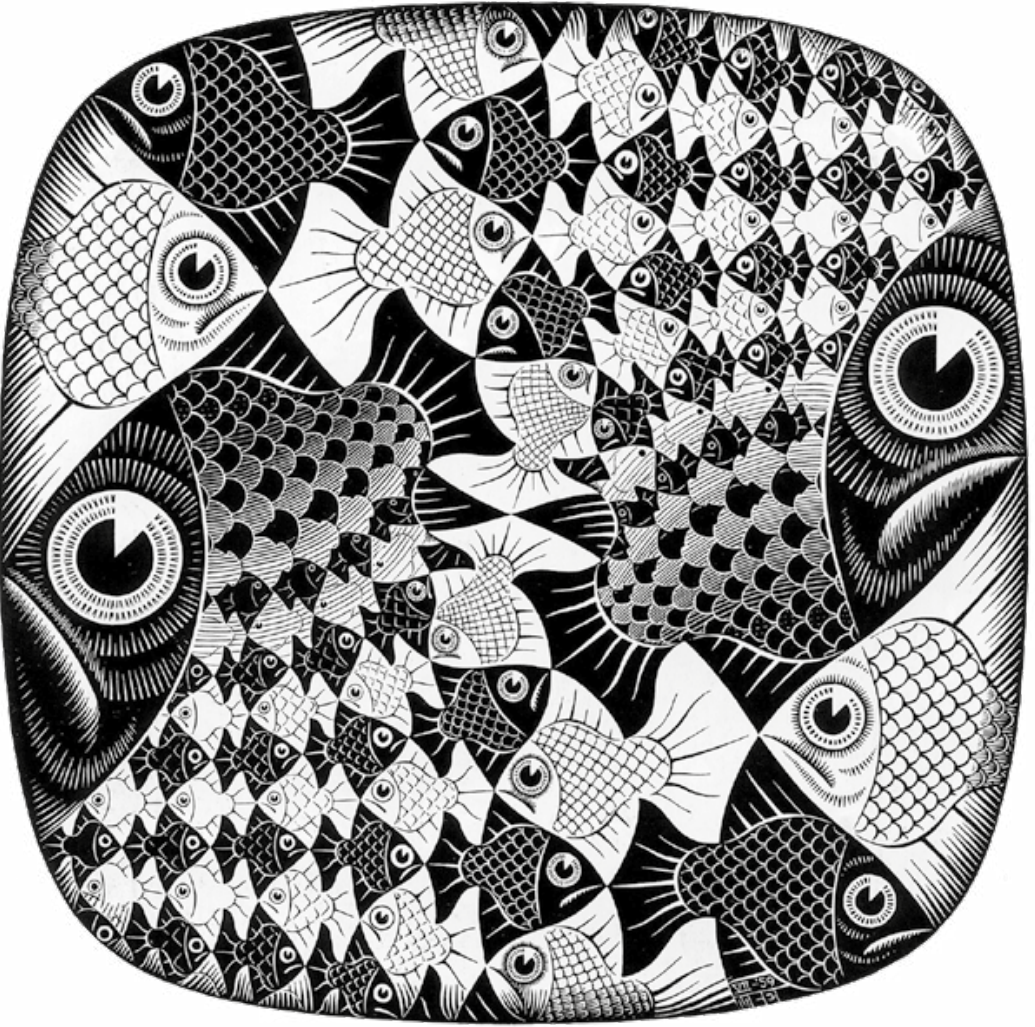

\section{Prof.dr Duur K. Aanen}

Inaugural lecture upon taking up the position of Personal Professor

of Evolutionary Biology at Wageningen University \& Research on

6 February 2020 



\section{Science and Myth in Evolution}

\section{Prof.dr Duur K. Aanen}

Inaugural lecture upon taking up the position of Personal Professor of Evolutionary Biology at Wageningen University \& Research on 6 February 2020 
DOI https://doi/10.18174/519183

ISBN 978-94-6395-373-3

(C2020, Prof.dr Duur K. Aanen; WU. All rights reserved. No parts of this publication may be reproduced by print, photocopy, stored in a retrieval system or transmitted by any means without the prior written permission of the author. 


\section{Science and Myth in Evolution}

Esteemed Rector Magnificus, Dear Colleagues, students, family and friends,

\section{Prologue. The farmer and the pastor}

My father loved to tell stories. I am starting this lecture with one of his favourite ones.

The story is about a farmer who is a member of the local church council of a small village. One evening, the council has an important meeting, but the farmer's pig will give birth. Farmers know that pig mothers sometimes become cannibalistic around birth so they eat their new-borns. So the farmer has to keep an eye on his pig and must skip the meeting. But the pastor insists that the farmer attends this important meeting. What to do? The pastor has a solution: the farmer and the pastor will change roles for an evening: while the

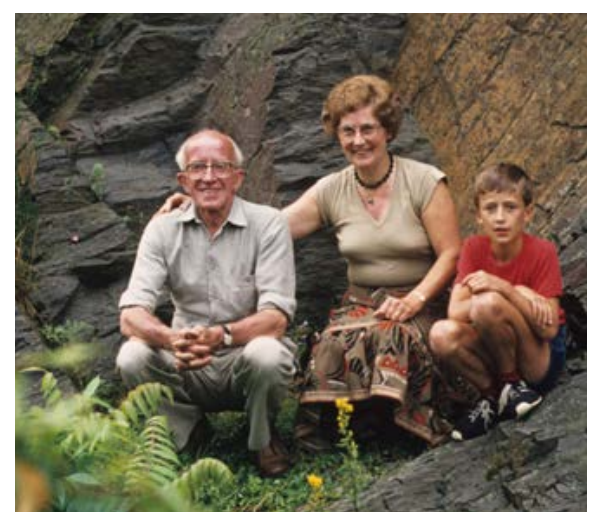

Figure 1. My father and mother and I

(photo: Eimert Aanen). farmer will discuss religious matters, the pastor will look after the pig that evening. The farmer agrees and attends the meeting while the pastor is midwife for an evening. The church council has a fruitful meeting, and the farmer goes home in a good mood. Back in the barn, he is just in time to see the mother pig swallow one of her just-born piglets and he runs to the pig in a desperate attempt to save the newly born piglet. To his great surprise, the pastor doesn't do anything and has a blissful smile. "Don't worry", he says, "A miracle is happening. The pig has eaten the piglet already 10 times. But every time, the piglet passes her mother unharmed. I am fully confident that this will happen again. Just wait and see." 


\section{Introduction}

What does this story teach us? This story illustrates that people can have completely different interpretations of one and the same thing. These interpretations can have different functions. The pastor's sense for the reality of nature is not particularly well developed, but the wonder he feels is functional for a pastor. In contrast, the farmer emphasises the natural causes of what he sees, and this is useful for him since he depends on his livestock for a living.

As a student and teacher of evolution I am also sometimes confronted with different interpretations of evolution. We may think of the problems of a small minority of religious people with evolution, but I want to start with a different example. For evolutionary biologists, the tragedy of the commons is an often-used analogy for the problem of cooperation (Hardin, 1968). The tragedy of the commons is a famous essay from 1968 by Garett Hardin who describes the common ground of a small medieval village, where the shepherds were allowed to have their sheep. Imagine a commons with space for 30 sheep divided over five shepherds (Figure 2). Each shepherd may be tempted to have more sheep. But what does one extra sheep mean? For the owner of the sheep it will mean the extra wool of one additional sheep. But the grass it will eat, will be shared with all farmers. So, a selfish farmer should put an additional sheep on the field. But the other farmers should follow the same logic, and not only for one additional sheep but also for the next extra sheep. Of course, this is not sustainable and will lead to overexploitation, which is detrimental for everyone. This is the Tragedy of the Commons.
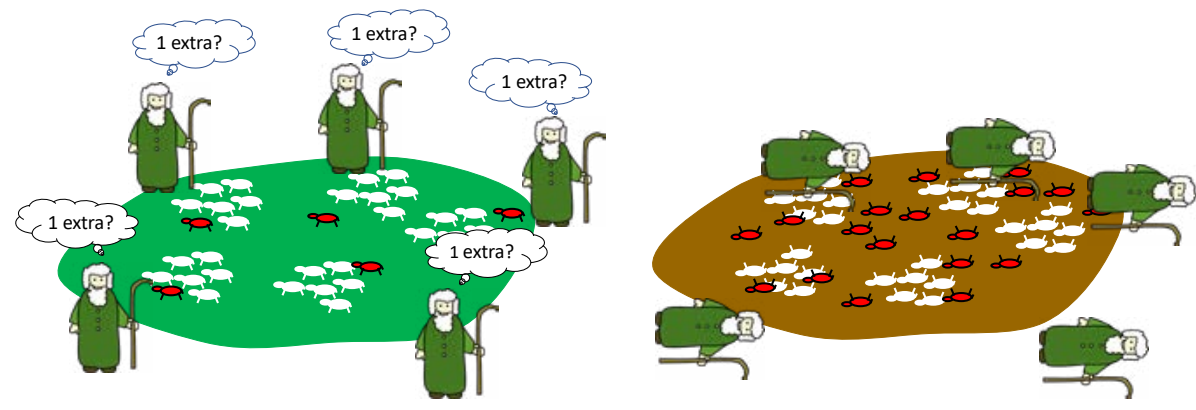

Figure 2. The tragedy of the commons (Hardin, 1968) is the story of a common ground of a medieval village. Since the benefit of extra sheep (wool, meat) is for an indiviual shepherd, but the costs (the extra grass consumed) for the community, an individual shepherd will be tempted to add additional sheep. But this is not sustainable, and will lead to overgrazing. 
An example of the tragedy of the commons in biology is the sex ratio in a population. In most animals, there is an equal number of males and females. If you think about it, there are far too many males. Females, not males, are the limiting factor for reproduction. Females have to carry their young during pregnancy, or to lay eggs and sit on them, while males only have to fertilize them and therefore, can mate with multiple females. So, this group of 10 elephant seals could have nine young if it consisted of nine females, and just one male to fertilize those (Figure 3). Yet, we see one male for each female, so the group has only five young. And even worse, there are harems. So there is one male with five offspring and four males without any. Why would animals have evolved equal sex ratios? The famous population geneticist Ronald Fisher gave the answer (Fisher, 1930). He showed that individual selection always favours the rare sex, so the evolutionarily stable sex ratio is fifty-fifty. Since each offspring has a father and a mother, the reason for this is that individuals of the rare sex on average have more offspring. So when the group consisted of nine females and just one male, the average fitness of males would be nine and that of females one. This is just one example of the tragedy of the commons, but there are many more in biology.
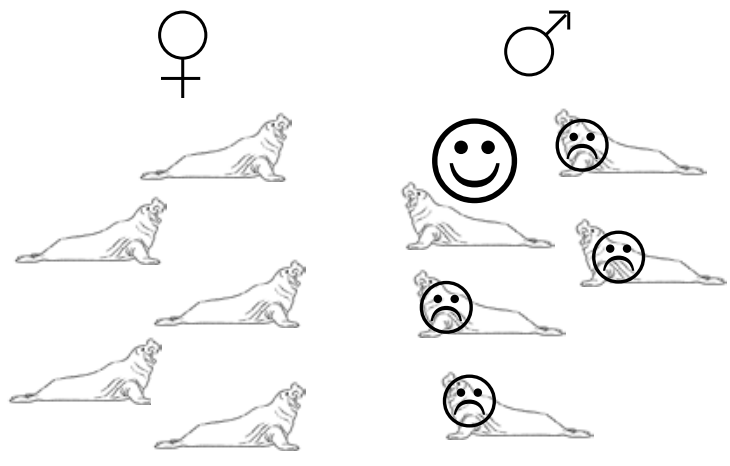

Figuur 3. The surplus of males is a tragedy of the commons, because a population consisting of more females could produce more offspring. However, although only one of the five males in this population of 10 elephant seals has offspring, and all five females, the average fitness of males and females is the same with an equal sex ratio.

I recently discussed the tragedy of the commons with Sylvia Karlsson-Vinkhuyzen. As a former member of Wageningen Young Academy, I know Sylvia who is a political scientist and studies human decision making in global problems such as climate change. We had a long-standing appointment to discuss the tragedy of the commons over lunch. To my great surprise Sylvia told me that this theory is highly controversial among social scientists, as this recent tweet shows (Figure 4). The validity of the analogy has been questioned - there rarely was a tragedy of the commons on the common grounds of small villages. On top of that the author of the essay has been accused of racism, eugenics, and white supremacy. 


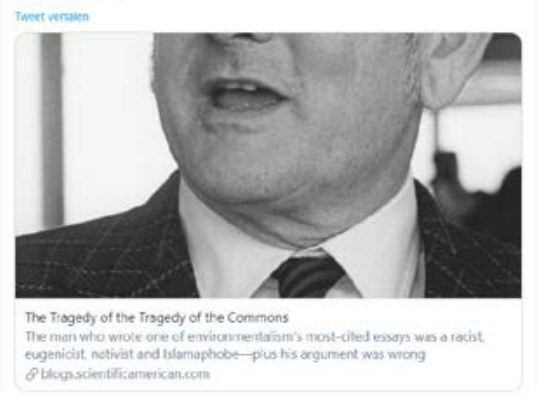

Figure 4. The tragedy of the commons is highly controversial among social scientists as this tweet illustrates.

But while preparing this presentation I have been wondering whether the controversy really is only about the science. To me, the intensity of the debate suggests there is more. Apparently, the answer to the question whether cooperation is the norm and whether it is stable, is important. And there is a difference between the biological example I gave and the social sciences, which I think is relevant here: the social sciences are about humans. So the tragedy of the commons is about ourselves. And about our own society. Although we tend to think we can separate science from myth, with science being factual descriptions of nature and myth the political, moral or religious implications, the above example shows how hard this can be.

Evolution in general is sensitive to mixing myth with science, since evolution also addresses our own origin, and the possible adaptive value of our own behaviour. My plan for this lecture is to tell you about research on the evolution of cooperation, its history and its implications, illustrated with examples from my research and teaching. At the end of my talk, I will focus on human cooperation and ask if there is a basis for the suspicion that evolution sometimes is more than science, namely also myth, that is to say a story with a moral.

\section{The problem of cooperation.}

The tragedy of the commons illustrates the difficulty to explain the evolution of cooperation. Yet, there are many examples of extreme cooperation. In social insects individuals even permanently give up reproduction. Take the fungus-growing termites. Here you see a colony. Inside this mound the workers cultivate fungi for food. All the workers and soldiers in a colony forego reproduction, except for the 
queen and the king. The queen can lay no less than 25,000 eggs per day, and all 100's of thousands of workers and soldiers help the queen and king produce more brothers and sisters. How can such extreme helping behaviour evolve?

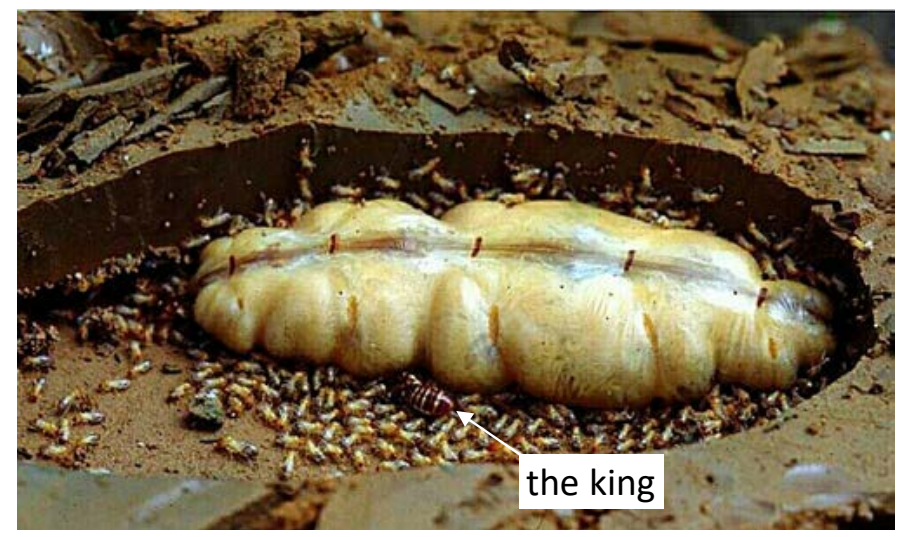

Figure 5. 'The royal pair' of fungus-growing termites produces all indivduals of a colony since the workers and soldiers are sterile. The queen can lay up to 25,000 eggs per day.

Charles Darwin was already puzzled by the extreme altruism he saw in the social insects which also include ants, bees, and wasps. He considered it to be a "special difficulty, which at first appeared to me insuperable, and actually fatal to my whole theory" (Darwin, 1859). He also hinted at a possible solution. While discussing the example of social insect workers, he used an analogy with oxen. Oxen are castrated bulls, so they are sterile. How could farmers select traits in sterile animals? Some breeds are famous for the horn length of the oxen, which are different from fertile animals, so how can such a trait be selected? Darwin realized that oxen traits could be indirectly selected via the fertile family members, so cows and bulls, of these oxen. So, although the fertile relatives of the oxen did not have the same characteristics, Darwin realized that they shared hereditary material.

It is interesting to have a small reflection on Darwin's ideas on heredity. Darwin, similar to most biologists in his time, believed in some form of inheritance of acquired traits. This theory was developed by the French biologist Jean-Baptiste de Lamarck. Some of the changes during an organism's lifetime were inherited by the offspring. The classical example is the giraffe's neck, as you can see here. Francis Galton, a cousin of Darwin, had a quantitative model of heredity. Here you see his diagram, published in Nature (Galton, 1898; Figure 6, left). I think it is nice to give you half a minute to look at it and perhaps discuss with your neighbor what you think of it. 


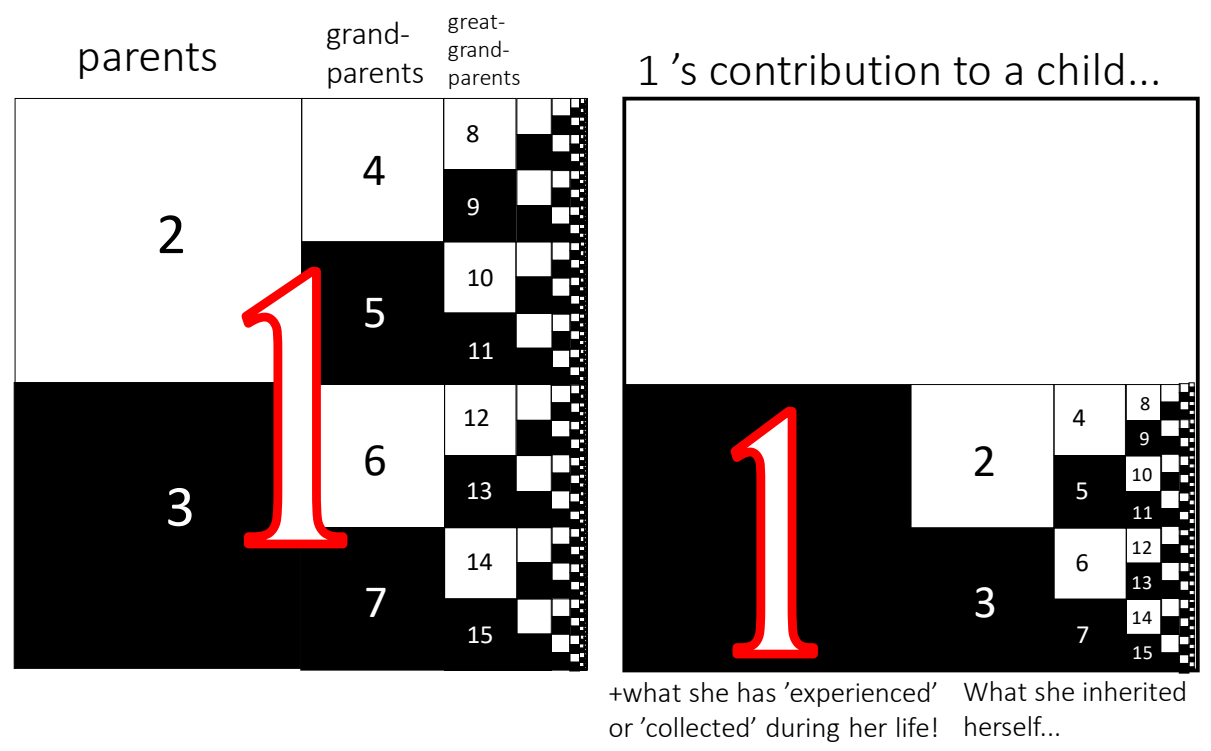

Figure 6. Francis Galton's model of heredity (1898). The left pane; shows the genetic composition of individual 1. White and black squares indicate male and female ancestors, respectively. The right panel shows what individual 1 contributes to her own offspring.

To understand Galton's model, it is helpful to see what individual one would contribute to an offspring. This is what she inherited herself PLUS what she acquired during her lifetime (Figure 6, right). Well, we now know that this is clearly wrong. After the rediscovery of the work of the monk Gregor Mendel (Mendel, 1866), we know that no new information is acquired during an individual's lifetime, except for a few random mutations.

\section{Kin selection.}

So even though Darwin's ideas on inheritance were wrong, he had an intuition of indirect selection in genetically related individuals. The famous population geneticist JBS Haldane was more specific and is famous for the following quote: "Would I lay down my life to save my brother? No, but I would to save two brothers or eight cousins!" So, he came close to the evolutionary explanation of altruism, which was further developed by Bill Hamilton (Hamilton, 1964). He provided the real theoretical underpinning of this idea. His major result is known as 'Hamilton's rule'. Hamilton showed that a gene for altruism can be indirectly selected in family members if the altruism is directed to genetically related individuals which have a certain probability to share the altruism gene. 


\section{Levels of selection.}

An alternative approach to understanding the evolution of cooperation is to determine at which level natural selection is important (Keller, 1999). I will explain with an analogy what I mean. To become a professor, I had to be assessed by a so-called BenoemingsAdviesCommissie, or BAC. The BAC assessed me, as an individual. But I am also part of a group, my own research group with students and postdocs and my team is part of the Chair Group Genetics. To some extent, my performance is positively correlated with that of my chair group. But there can be a tension between individual interests and team performance. Take a common task such as management. The time I spend on management, that is to say, the extra time above the minimum requirement for management, cannot be used for doing research, writing papers or writing grant proposals. So, it is in my own interest if someone else in the chair group does the extra task. But if all my colleagues follow the same logic, no one is going to do it, except for Bas I guess. Too much emphasis on the individual may favour strategies to minimize contributing to common tasks for the group.

So, I think it is fair to say that there is a certain tension between the assessment of an individual and the assessment of a group to which this individual belongs.

In biology, a similar tension exists between assessment at the level of an individual and assessment at the level of a group. However, while I am assessed by a BAC and groups are evaluated by visitations and review committees, assessment in biology takes place by natural selection. Or, in agriculture, by artificial selection. And while a BAC decides on promotions, natural selection decides on survival and reproduction of individuals or groups resulting in adaptive evolution.
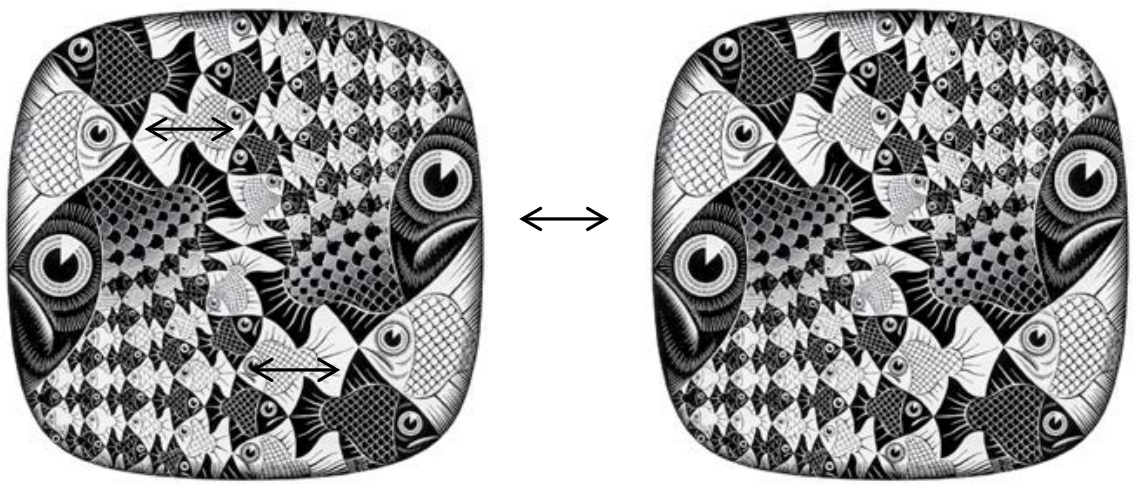

Figure 7. Selection at two different hierarchical levels, between individuals within a group and between groups. 
Take this image, there can be selection among individual fish, indicated by swimming in different directions, but also between groups of fish (Figure 7). If groups of fish that cooperate, for example by swimming in the same direction, outcompete groups of fish that do not cooperate, genes for cooperation are favored. However, within a cooperating group, a fish that profits from the others swimming and does not contribute will save resources for individual reproduction and thus be selected at that level. So there is a conflict between selection at the level of the individual, and selection at the level of the group.

\section{Own research}

In my own research I do not use fish, but fungi, as a model for the evolution of cooperation. The mycelium is the fungal multicellular individual (Figure 8 ). On the one hand, the fungal mycelium is a collective itself, of many nuclei, which cooperate to form spores. On the other hand, the mycelium can be an entity of a larger collective, so a group of mycelia, for example inside a colony of fungus-growing termites. Similar to an assessment that can occur at the level of the individual researcher or of the chair group, natural selection can also act at these different levels. The nice thing of fungi is that they have fast generations, and large populations so that we can experimentally study evolution. Also, mycelia can fuse or reject each other, so we can play with the level at which selection is most important.
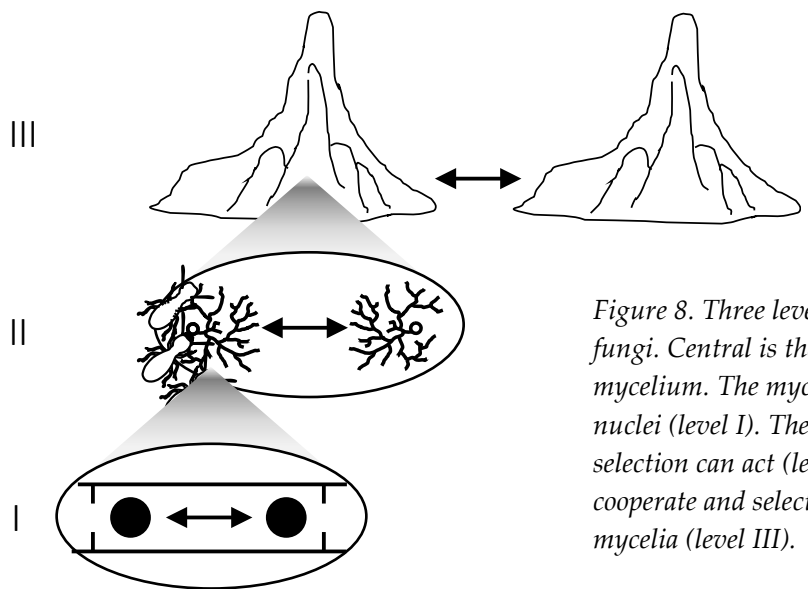

Figure 8. Three levels at which selection can act in fungi. Central is the fungal individual, the mycelium. The mycelium is a colony itself, of nuclei (level I). The mycelium is an entity at which selection can act (level II). Mycelia can also cooperate and selection can act among groups of mycelia (level III).

In Figure 9 you see that illustrated, interactions between fungal individuals range from successful fusion to fusion followed by cell death and antagonism. Successful fusion is generally limited to very closely related individuals. Unrelated individuals reject each other, which you sometimes can see as those barrages in wood. This can also be used for decorative purposes as in this spalted wood. 

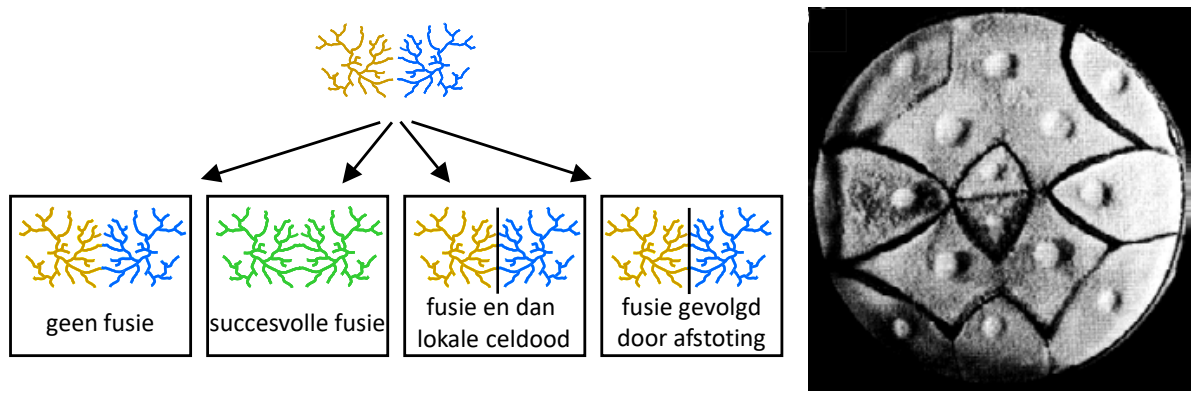

Figure 9. possible social interactions among fungal individuals (left). Rejection responses can be seen macroscopically in Petri dishes (top right), and also in wood, such as in this spalted wood (bottom right). The lines are the result of rejection responses between different individuals, and indicate the borders where two fungal individual come in contact.

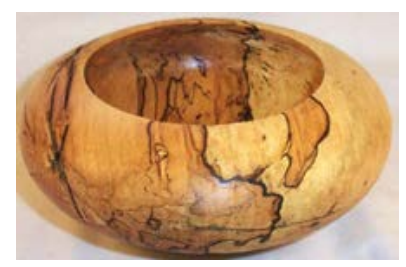

Free fusion maximizes cooperation (Bastiaans et al., 2015). In 2009, we discovered that the fungus-growing termites I showed before, grow their fungi as a monoculture. We could show that in a monoculture, the germinating spores freely fuse, and that this maximizes the fungal yield for the termites, as Figure 10 shows (Aanen et al., 2009).

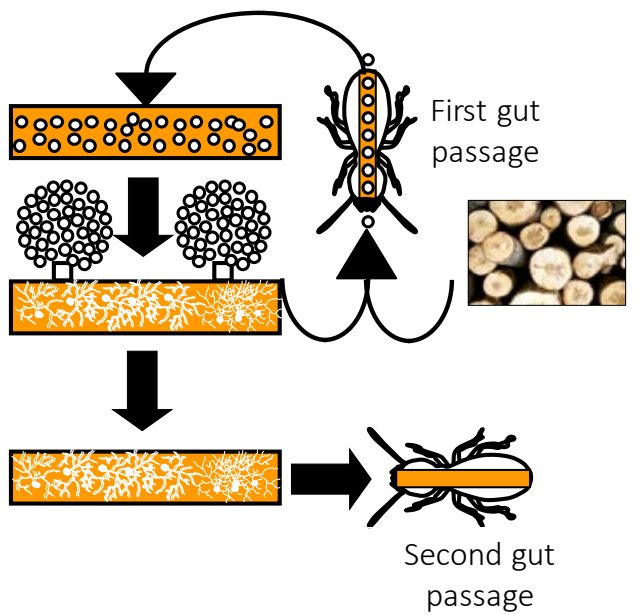

Figure 10. Fungus-growing termites grow fungi in their colonies on a substrate of plant material. The plant substrate is inoculated with asexual spores, which then germinate and colonize the substrate. Termites grow their fungi in monoculture. In a monoculture, germinated spores can freely fuse, and the photographs in the right panel show that this maximizes fungal yield (Aanen et al., 2009).
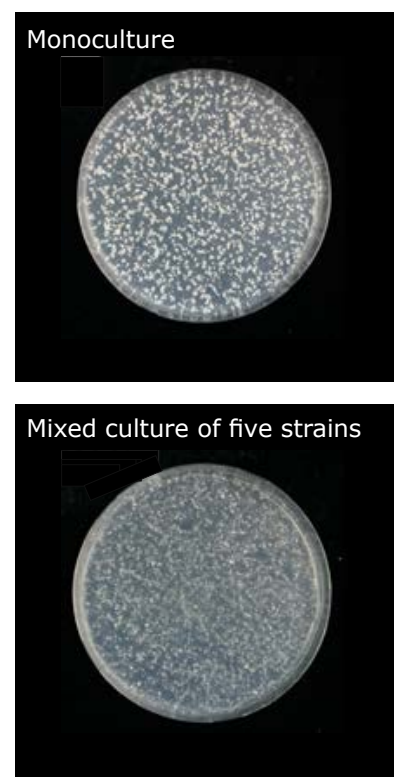
However, even though free fusion maximizes cooperation, it is also risky because cheater mutants may arise, which fuse but do not contribute to the cooperation. Using experimental evolution, we have recently shown that this is a real problem (Bastiaans et al., 2016). A major research theme is how cheating works, and how cheating can be prevented.

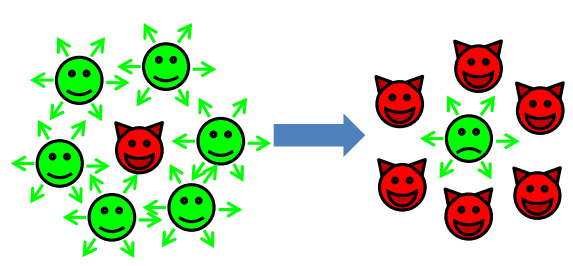

Picture by Eric Bastiaans
Individual competitiveness

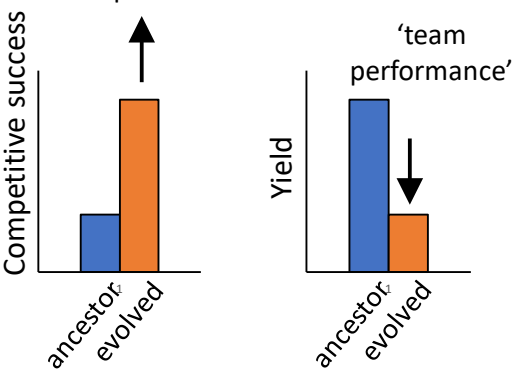

Figure 11. In a monoculture, free fusion can lead to a Tragedy of the commons, since cheating nuclei can profit from thgeir neighbours. The right panel shows that this is indeed the case, and leads to an increase in individual competitiveness, but a decrease in collective performance, viz. reduced spore yield.

\section{Darwinian Agriculture}

Insights in the levels of selection can also be applied. There is an interesting example from social scientists who studied the effect of individual talent, measured by the transfer value of each player, on team performance in team sports (Swaab et al., 2014). It turned out that there was an optimum (Figure 12, left). They called this the too-much-talent effect: obviously you need some talented players in a team, but too many top players in a team reduces team performance. This is another example of the trade-off between competitiveness and collective performance.
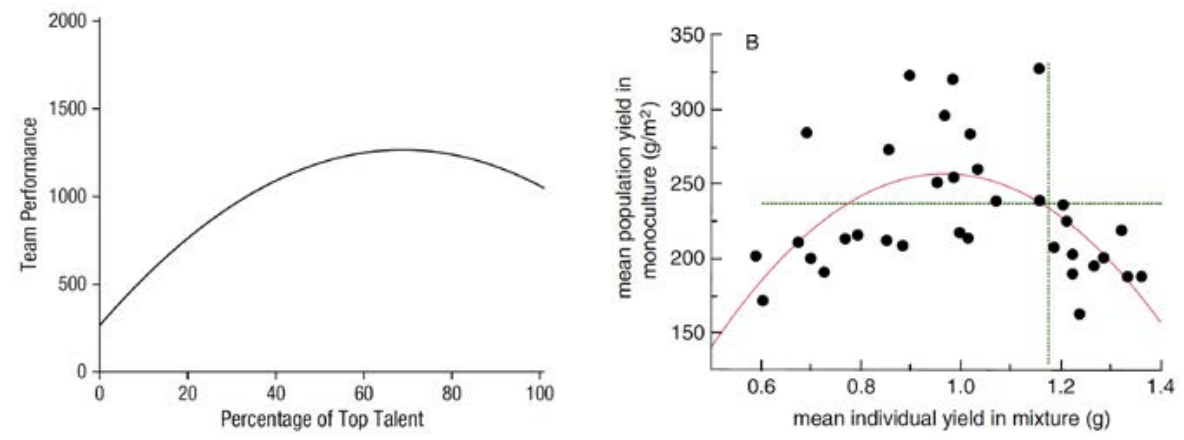

Figuur 12. The too-much-talent effect in teamsports (left) and in mixed cultures of wheat. 
A remarkably similar phenomenon can also be seen in cultivated crops such as wheat. In Figure 12 (right) you see the results of an experiment on wheat published in 2017 (Weiner et al., 2017). On the y-axis you see the mean population yield in monoculture of a variant, and on the x-axis the competitive success in a mixed culture. As you can see, a little bit of competitiveness is good for yield in monoculture, but above an optimum, collective success in monoculture is lower with increased competitive success. Almost exactly similar to the too-much-talent effect in team sports.

In fact, the green revolution leading to a spectacular increase in the yield per hectare of rice and wheat, is mostly based on selection for plants with shorter stems. Shorter stems means less competition for light. Per plant, and also per hectare more rice was harvested, because more of the resources were invested in the seeds. At our university the group of Niels Anten studies the trade-offs between plant competitive traits and collective success.

Also in animal breeding those insights can be applied. Here you see the result of a classical experiment by Bill Muir in 1996 (Muir, 1996). Individual-level selection for survival paradoxically led to an increase in mortality. The explanation is that the individuals surviving were the most aggressive ones. Selecting at the level of family groups did lead to an increase in longevity because more social individuals were selected. In Wageningen, the group of Piter Bijma applies these insights in animal breeding to select for social animals, which can peacefully live in groups. Indeed, there is a whole new field, called Darwinian agriculture, that applies the levels of selection theory to agriculture (Aanen, 2013; Denison, 2012).

\section{Human cooperation}

Can we apply the theory derived for the evolution of cooperation among nuclei of fungi, or for cooperation between ants or bees, to our own species? Well, as you noticed, I have used several examples from human cooperation, but I was not particularly optimistic as my assumption was selfishness: individuals make strategic decisions for their personal benefit. This assumption is the basis for the tragedy of the commons. But my interaction with social scientists already taught me that this evolutionary perspective of human interactions based on selfishness is not shared by everyone.

How can we understand this? Some years ago, together with Michel Handgraaf, a behavioural economist at this university, we did an experiment with students in the course Evolution and Systematics. This experiment was based on an important study by Ernst Fehr and Simon Gächter published in Nature (Fehr and Gachter, 2002). The 
game tested cooperation among students and the effect of punishment on cooperation. The game was a 'public goods' experiment with real money. Groups consisted of four anonymous members. Each member received $20 €$ and could contribute between 0 and $20 €$ to a group project. Students could keep the money that they did not contribute to the project. For every $€$ invested, each of the four group members, that is, also those who invested little or nothing, earned $0.4 €$. Thus, the investor's return from investing one additional $€$ in the project was $0.4 €$, whereas the group got $1.6 €$. Because the cost of investing $1 €$ in the project was exactly $1 €$, whereas the private return was only $0.4 €$, it was always best to keep all money. But if all group members kept their money, each student keep their $20 €$, whereas if all of them invested their $20 €$, each would earn 0.4 X $80=32 €$. The game was played for six rounds, every time in different compositions, and anonymously.

Here are the results (Figure 13). What you can see is that students are more social than if their decisions would be purely selfish. You can also see that over time, they become more strategic and cooperation breaks down. This may partly be explained because the students start to understand the game while playing, since it is not an intuitive game.

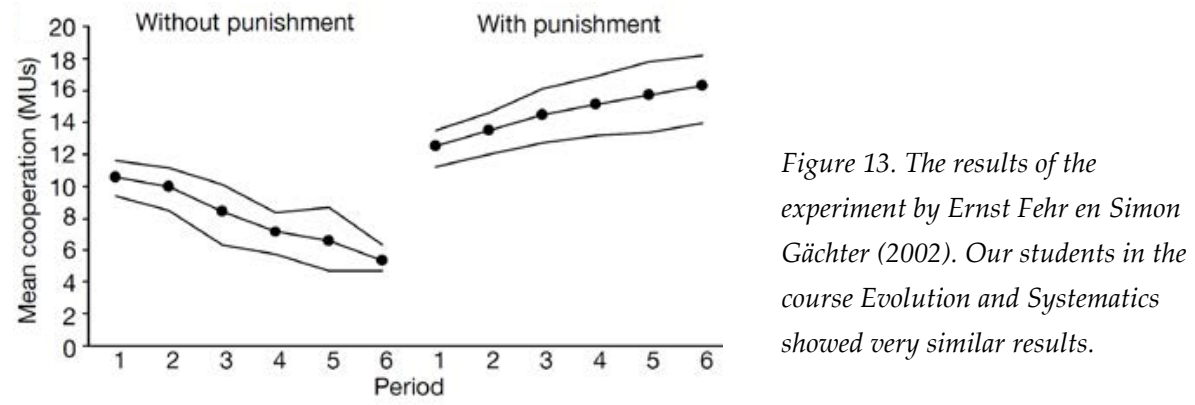

However, we also did a separate experiment, where students had the option to invest some money in punishing of group members who did not invest. Punishing is costly, so it is an act of altruism. Here you see the results. Interestingly, students were willing to punish and now cooperation increased almost to the maximum (Figure 13, right).

So the social scientists are right: we are too social, at least more social than makes sense based on selfish motives, which is the assumption underlying evolutionary predictions. In particular, we have a well-developed sense of morality, so of what is right and wrong, and we are willing to punish asocial behaviours. How can we understand this? 


\section{Culltural evolution}

Clearly, compared with other mammals the scale at which cooperation occurs in humans, and the extent to which there is division of labour are unique (Figure 14). But there is an important difference between humans and other organisms: we have culture. At our university, Professor Gert Jan Hofstede studies culture and cultural differences among groups, and also the role of culture for human cooperation. In preparation of this inauguration I read this book by Peter Richerson and Robert Boyd, called 'Not by Genes Alone. How culture transformed human evolution' (Richerson and Boyd, 2005). The authors define culture as 'information capable of affecting an individual's behaviour that is socially transmitted'. There are numerous examples. Think of tool use. Or professional traditions such as farming. Farming is a technique and also a way of living. There are certain traditions, which can be very different between different countries or even regions within a country. Those differences are not encoded in our genes.

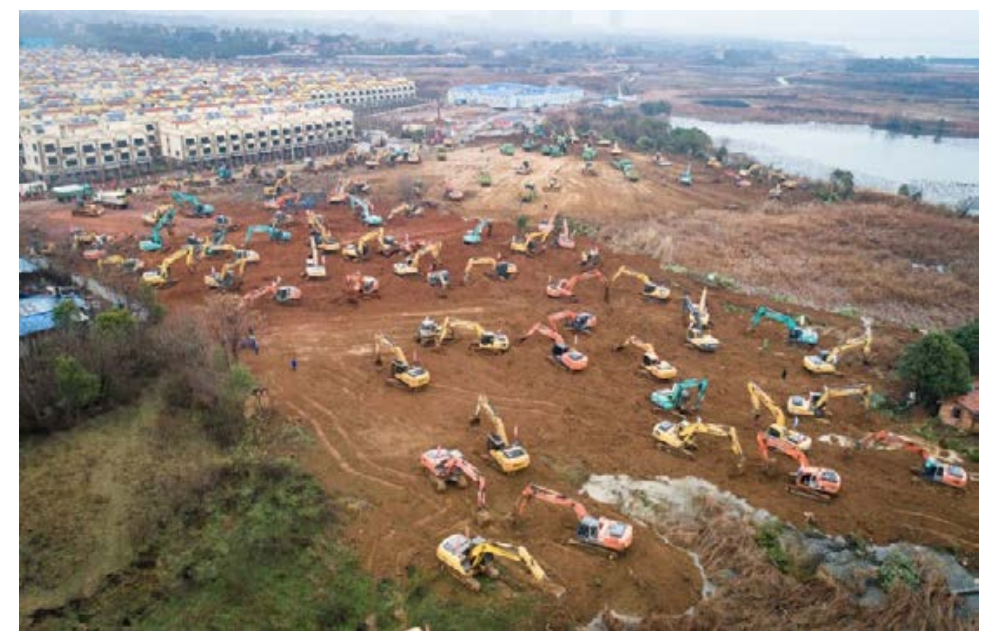

Figure 14. The scale and the degree of division of labour in human cooperation are unique. Here you see the building of an hospital in China because of the corona-virus outbreak, in less than 10 days.

Nevertheless, culture is inherited. And as we saw, there can be different cultural variants. And importantly, different variants can have different 'reproductive success': some variants are transmitted to many individuals, while other ideas die out quickly. Indeed, these three characteristics are exactly the conditions required for adaptive evolution: there is variation that is heritable, and that affects reproductive success. But now we are not talking about genes encoded in our genome, but about ideas encoded in our brains, our books and computers. 
So, in contrast to DNA, we do acquire all kinds of new ideas from our social environment. And the rate with which this occurs has only increased recently, just think of the difference in mobile-phone skills between me and Cornelia and Hanna, my daughters. Let alone the ideas that spread via social media and 'infect' our brains. It is interesting to consider Francis Galton's model of acquired inheritance for cultural characters. Even though we now know that Galton's model was wrong for DNA-based inheritance, it may actually be quite accurate for cultural inheritance. After all, an individual learns from her parents, who on their turn each have learnt from their parents, and so on. But on top of that, each generation individuals also acquire knowledge from their social environment. And they transmit some of that acquired culture to their children.

Richerson and Boyd argue that the unique ability of humans to learn and imitate has allowed the colonisation of the extremely diverse environments that we live in across the globe. And cultural adaptation can be much faster than genetic adaptation. They give as an example what people have to know to live in arctic regions (Figure 15). They have to know how to make kayaks, warm clothes, harpoons, oil lamps, housing. They also have to know how to use all that stuff, and when. And crucially: Even though humans are clever, it is impossible for an individual to acquire all those skills and knowledge from scratch. However, arctic foragers could make use of a common pool of knowledge and ideas that they acquired via social learning from others. If new variation arises during this copying process and it is more successful, this behaviour can spread by being imitated more often. So, copying successful (or common) ideas is much faster. Different rounds of learning and imitation can lead to cumulative cultural evolution.

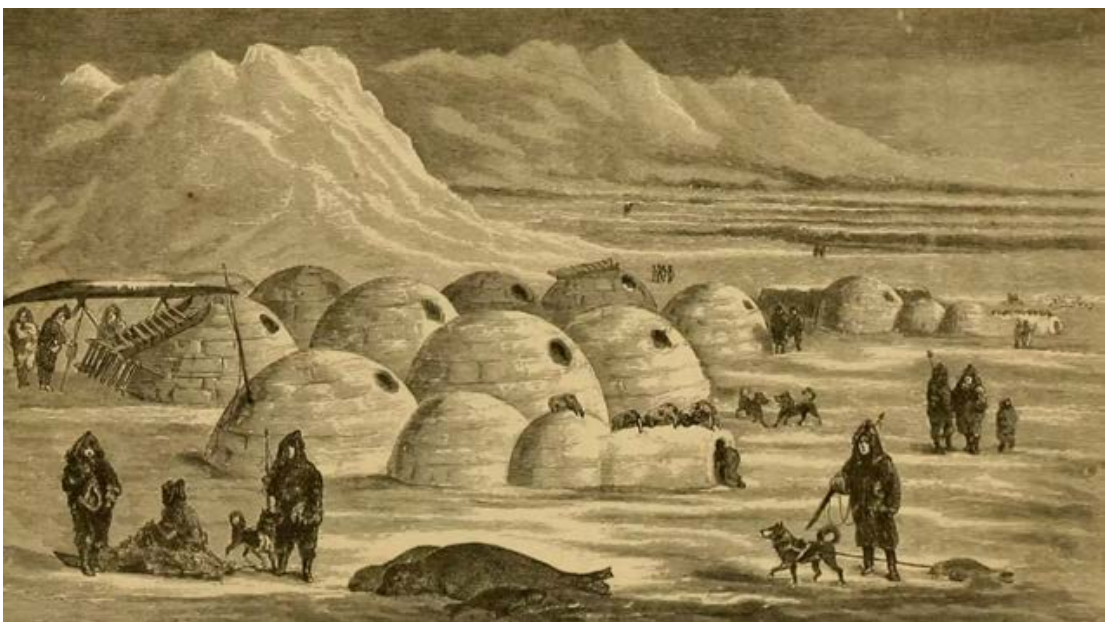

Figure 15. Surviving in arctic areas requires extensive knowledge and highly diverse skills. 


\section{Cullture and cooperation}

Richerson and Boyd believe that culture has been crucial for the evolution of human cooperation. Their argument is as follows. Humans evolved social learning, creating the possibility of cumulative, non-genetic evolution. Rapid cultural adaptation to different environments increased heritable variation between groups, also in the level of cooperation. Competition between groups then led to the spread of behaviours that enhanced the competitive ability of groups. For cultural group selection to work, group identification is crucial. It seems that our species is very well able to have group identification. Indeed, this is not always based on genetic relatedness, as this example shows (Figure 16). The final part of the argument of Richerson and Boyd is that in the new social environment created by cultural adaptation, natural selection favoured genetically determined new derived social instincts. Once social norms became adopted, there was natural selection against antisocial behaviour. This part of their theory is the most controversial and is not generally accepted. But the work of Richerson and Boyd, and others in the areas of cultural evolution such as Yuval Noah Harari (Harari, 2014; 2016), convincingly shows that cultural evolution is a significant force in human evolution.

\section{This Fridge}

\section{is for}

\section{BIOSCIENCE}

people

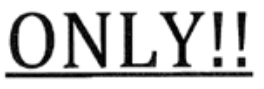

Figure 16. Humans have a special ability of group identification, which very often is not based on genetic similarity, as this example shows. This picture hang on a fridge of one of the science groups in the Radix building of the Wageningen Campus.

\section{Controversies}

Even though we can apply evolutionary logic to our own species, even to its cultural evolution, there are controversies between evolutionary biology and humanities and social sciences, as the tragedy of the commons illustrated. So what is the problem?

\section{Language matters}

Some misunderstandings are due to language. I give two examples to illustrate what I mean. The first is about teleology, so explaining phenomena in terms of the purpose they serve rather than of the cause by which they arise. An example is: "Plants grow 
up towards the light because plants want to maximize the amount of light they receive". Since Aristotle teleological language has been used, but since Darwin there is a scientific justification for such language: natural selection favors traits that are adaptive, so are functional for survival and reproduction (Okasha, 2018). What evolutionary biologists mean is that natural selection favored genes for phototropism, because individuals with this trait had a higher chance to survive and reproduce. Second, when we evolutionary biologists speak of terms such as altruism or selfishness we refer to the consequences of a certain behaviour for direct fitness. And we can come up with evolutionary explanations for such behaviours. However, we do not refer to mental states of individuals, which is the ordinary use of these terms, or to morally good or bad behaviours (Scott-Phillips et al., 2011). So language matters, and evolutionary biologists sometimes have a blind spot for the consequences of the language they use.

\section{Science and myth belong to different categories of knowledge}

A more fundamental problem is: What do we expect from evolutionary biology? Do we expect evolutionary explanations can provide moral justification of certain behaviors? Even though we will say ' $\mathrm{No}^{\prime}$, the example of social Darwinism in the $19^{\text {th }}$ century shows that this has not always been so. But although we have rejected social Darwinism and eugenics, equating adaptive explanations with moral justification still occurs, especially in popular media. In the essay Science, Ideology and Myth (Maynard Smith, 1988) John Maynard Smith described an interesting case: evolutionary explanations for homosexual behaviour. Maynard Smith argues that some people expect that adaptive explanations for homosexuality may give a moral justification. So if there would be no adaptive explanation, the behavior would not be justified. Maynard Smith is very rigorous in his rejection of this idea. He formulates it as follows: "If people have despised gays because gayness does not contribute to biological fitness, they have been wrong to do so. It would be as sensible to persecute mathematicians because an ability to solve differential equations does not contribute to fitness. A scientific theory - Darwinism or any other - has nothing to say about the value of a human being."

Maynard Smith goes on to argue that it is crucial to separate stories with a moral message, so myths from science. Science can never be a direct source of moral guidelines, so science is not a myth. Ultimately, I think, the problems a minority of religious people has with evolution, and vice versa the problems a minority of evolutionary biologists has with religion, is also due to mixing myth and science. The origin of species is not a book with moral guidelines for our behaviour. Likewise, the Bible is not a book with scientific explanations for the natural world. In 2018, Gijsbert van den Brink and I organised a symposium on this topic, with a highly diverse group of scientists and teachers, philosophers of science, evolutionary biologists, and 
theologians, and with highly diverse secular and religious backgrounds (Figure 17). This symposium was highly constructive, and we were happy to present The Leiden Declaration on Evolution and Religion, which was signed by the overwhelming majority of participants.
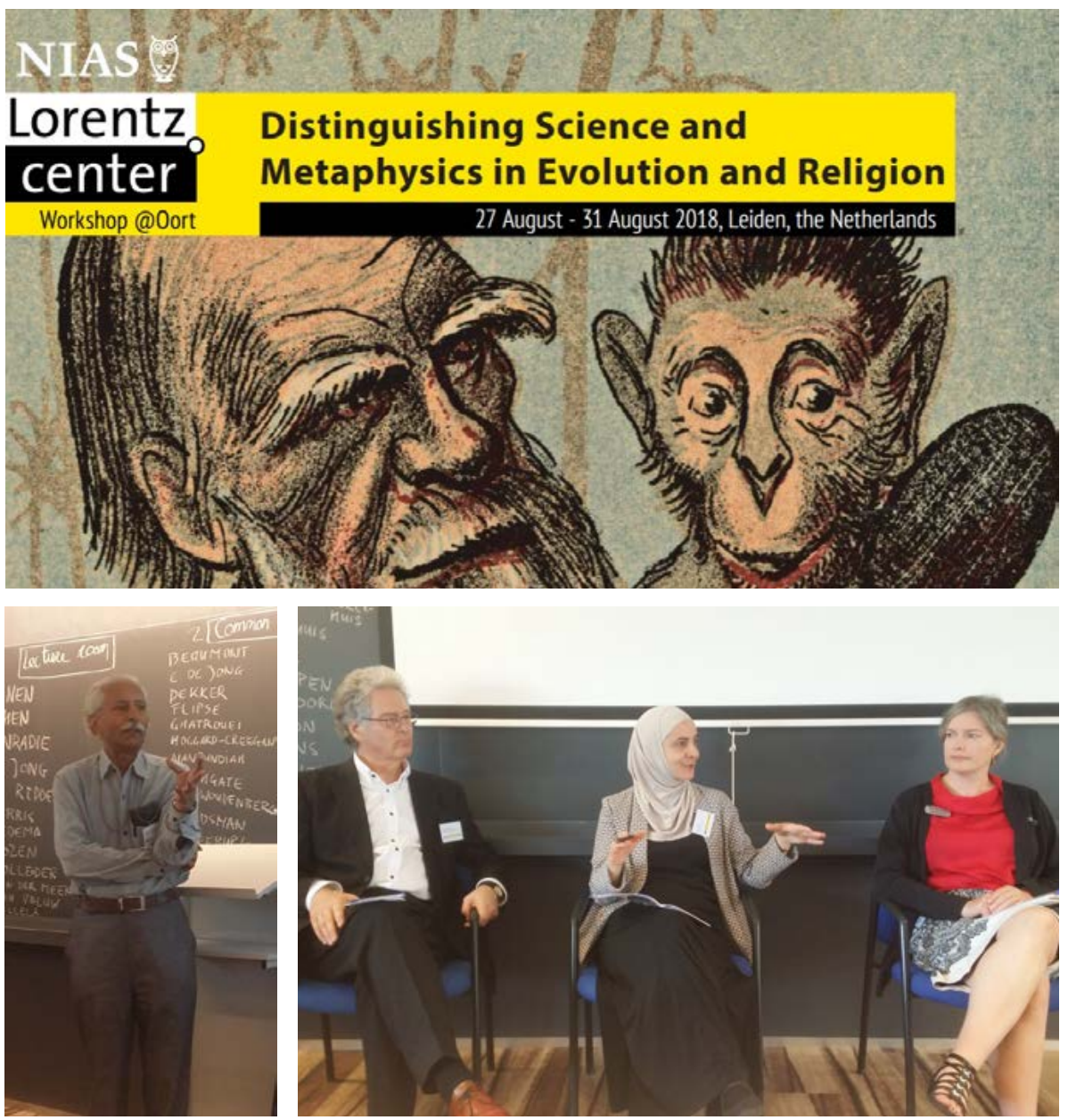

Figure 17. The Lorentzcenter workshop Distinguishing Science and Metaphysics in Evolution and Religion (27-31 augustus 2018, Leiden) was a great success and has resulted in The Leiden Declaration on Evolution and Religion www.leidendeclaration.com, which was signed by the overwhelming majority of participants. Here you see (left to right) Vidyanand Nanjundiah, David Livingstone, Rana Dajani and Deborah Haarsma. 


\section{Take-home message}

Even though it can be debated whether there are any fundamental differences between humans and animals, I think it is fair to say that there are some big differences. In particular when it comes to cultural inheritance. Nevertheless, to understand our behaviours, we can apply evolutionary logic to humans, not only to our genetic inheritance but -perhaps paradoxically- also to our cultural inheritance.

I started this lecture with the story of the pastor and the farmer. That story showed that it can be problematic if a single event is the basis of two stories with different functions. Evolutionary biology is another example where problems arise when science and myth are mixed. Science and myth are different kinds of knowledge. In an ideal world, science is about the objective facts, and myths are 'stories with a moral', so stories communicating how we should live, and what we should do with the scientific knowledge. We do need both the science and the myths, but we should be very clear that they are different.

I hope I have made clear that evolutionary biology is a science and not a myth, so it is not a source of moral guidelines. However, this message applies to all science: we can hardly underestimate the importance of basic science that is not directly influenced by political, applied or ideological motives. I am looking forward to contribute to the science and teaching of evolution, and to convey this message the coming years. Again, perhaps paradoxically, by downplaying evolutionary biology, I hope to increase its acceptance as an ordinary, yet very important and unifying, discipline in biology.

\section{Dankwoord}

Tenslotte wil ik nog een aantal mensen bedanken. Ten eerste mijn ouders voor hun stimulans en de vrijheid die ze mij gaven om mijn eigen interesses te volgen. Mijn vader zocht altijd naar verbinding tussen mensen van verschillende overtuigingen. Hij vertelde mij als klein kind over evolutie, maar ook over het christelijk geloof en

bij het avondeten las hij een -vaak actueel en toepasselijk- Bijbelverhaal voor. Hij was die boer die lid was van de kerkenraad, en hij wist dat er een verschil is tussen wetenschap en verhalen met een moraal. En mijn moeder was de zorgzame vrouw die me soms misschien iets te veel vertroeteld en beschermd heeft, waar ik helemaal geen aanleiding voor gaf.

Dan wil ik Thom Kuyper bedanken die mijn begeleider was bij mijn promotie en de eerste was die mij de schoonheid en het nut van schimmels voor evolutionair en ecologisch onderzoek heeft leren kennen. 
Rolf Hoekstra was mijn promotor, en ik ben ontzettend dankbaar voor je advies, wijze woorden en vriendschap. En in het bijzonder je relativeringsvermogen. Ik hoop dat ik er wat van geleerd heb.

Na mijn promotie heb ik een postdoc gedaan in Kopenhagen, bij Koos Boomsma. Koos, ik vind het ontzettend leuk dat je hier bij bent, en ik heb ontzettend veel van je geleerd in mijn tijd in Kopenhagen en ook daarna.

I also would like to thank Michael Poulsen with whom I have been collaborating a lot in the last years. I hope to continue that for the coming years.

Next, I would like to thank Bernard from South Africa. Bernard, we met for the first time in Oslo at the breakfast of the international mycological conference. We happened to be hosted in a birth clinic, which had some places left for conference attendants. The irony was that our wives both were pregnant at that time. Being surrounded by young mothers and small babies made us somewhat nervous being so far from home. A year later you hosted me for the first time in South Africa and I have been there often since. I really want to thank you very much for your hospitality and friendship, and also your colleagues Mike Wingfield and Wilhelm de Beer. I am very happy that you have come to this occasion. Also a warm welcome to Barend Erasmus from the University of Pretoria.

Also thanks to Tamas Czaran from Budapest for our long-lasting and stable cooperation to study the evolution and stability of cooperation.

Dank ook aan Gijsbert van den Brink voor de prettige samenwerking van de afgelopen jaren bij discussies over de interactie tussen religie en evolutie.

Ik wil ook alle collega's van erfelijkheidsleer bedanken voor de fijne samenwerking en goede sfeer. In het bijzonder wil ik Bas bedanken, niet in de laatste plaats voor jouw rol in de groep en het coördineren van The Levels of Assessment. Ook wil ik Fons speciaal bedanken, voor je ongelofelijke energie, kennis en creatieve inbreng, en de fijne samenwerking. En natuurlijk Arjan. Arjan je bent een ontzettend fijne collega, ik ga nooit met tegenzin ons kantoor in, en we hebben vaak goede discussies, soms wetenschappelijke, soms ook niet-zo-wetenschappelijke. Wytske, ook jou wil ik speciaal bedanken voor je rol in de groep.

En natuurlijk wil ik speciaal mijn groep bedanken, Sabine, Margo, Eric, Anouk, Mathijs, Lennart, Ben en ook Alex en alle studenten, dank jullie wel voor jullie inzet en de ontzettend fijne samenwerking. 
Dan wil ik mijn vrienden bedanken en de teamgenoten van zaalvoetbal. Het is goed om ook een leven buiten het werk te hebben, bij voorbeeld tijdens onze jaarlijkse biologenweekends en het pinksterkamperen met de families.

I want to say a special thanks to Lisbeth and Niels Erik. I am happy that you came all the way from Denmark and my family and I are very glad for our friendship.

Familie: Marian en Karen, Arie en Inge, Eimert en Anja, en neven en nichten, jullie ook bedankt voor de steun en het gezelschap en het bespreken van politiek en vooral natuurlijk de laatste ontwikkelingen bij Ajax. Ik hoop, en verwacht eigenlijk ook wel, dat jullie me nu eindelijk serieus zullen nemen en Karen, hopelijk ben ik nu eindelijk van het jongste-kind-complex verlost.

Also thanks to my brother and sister in law, Ole and Jette, and nephews Kasper and Mads, for your support, hospitality, great meals and hygge.

Tenslotte wil ik mijn naaste familie bedanken: Birgith, Hanna en Cornelia. Birgith, dank voor je liefde en je bereidheid 14 jaar geleden na mijn zes jaar in Denemarken de sprong in het diepe naar Nederland te wagen. Je bent inmiddels zeer geïntegreerd en een gewaardeerd bestuurslid en vrijwilliger van verschillende verenigingen in Renkum. En Hanna en Cornelia, jullie zijn de liefste kinderen die we ons konden wensen.

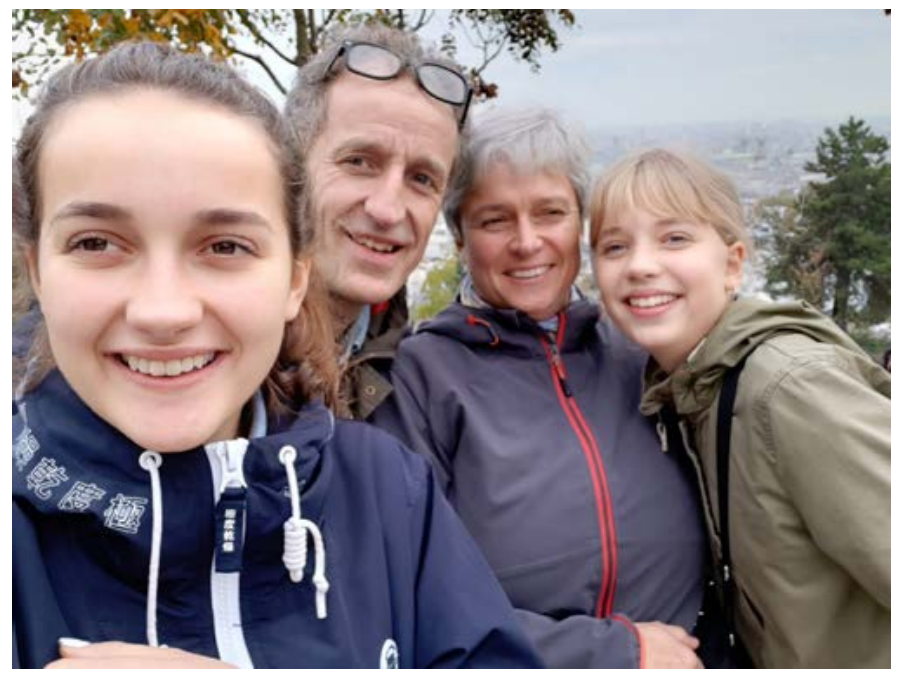

Figure 18. Our family: Cornelia, I, Birgith and Hanna in Paris (October 2019).

Ik heb gezegd. 


\section{Epilogue}

[This is an email I sent to the participants of the Lorentz workshop after a funny experience on the final day of the workshop Distinguishing Science and Metaphysics in Evolution and Religion]

"Dear participants,

I would like to share a story with you, which may be of relevance for the topic of our workshop. This story is based on the event I told you about yesterday at the end of the workshop. I also think this story may serve as a test to check what I hope I personally have learnt from this workshop. So, theologians, philosophers, but also biologists or participants from other disciplines, please let me know when you disagree with my interpretation.

$:-)$

Yesterday morning, on my walk to the Lorentz Center from the hotel, the bridge next to the hotel was open because a ship had to pass, so I had to wait. As Mathijs, Sander and Gerard can confirm, the name of the ship we had to wait for was.... 'Evolutie', which means 'Evolution'! Yesterday, I told you that I did not have a symbolic (or religious, if you will) interpretation of this incident yesterday morning, but after a night of deep sleep I have one. Please judge for yourself if you find my exegesis credible:

"Evolution can sometimes be an obstacle on our journey. However, when we give evolution the right place, we can let our resistance against it go, and we can continue our journey. Evolution should not stop us from continuing our journey."

Perhaps it is telling that the boat was not called 'Religion'. My interpretation of that is as follows:

"Religion cannot be an obstacle on our journey."

Now the obvious next question is: What do I mean with "our journey"? I would argue that the meaning of our journey is relative, depending on persons and circumstances. For scientists, it seems most relevant to interpret journey as: the journey to scientific knowledge. For religious believers, it seems most logical to emphasize their journey to God or other religious knowledge or revelation. Of course, as several participants of our workshop have testified, a single person could simultaneously be on multiple journeys, for example a religious scientist. 
I think this example could serve to illustrate some aspects relevant to our workshop:

1. The difference between literal truth and interpretation. I do not see any way in which I can prove that my interpretation is true in the literal sense. However, my interpretation can contain a truth for me personally.

2. Even whether my observation is a fact, viz. that the boat causing us to stop was called Evolutie, is subject to doubt. I did not have the presence of mind to make a photograph. And even if I would have had, this photograph might still not have provided sufficient evidence to convince a sceptical person... However, the presence of three witnesses lends some credibility to my observation.

3. There are other interpretations possible. As Gerard pointed out, a possible scientific explanation is that we were primed to see the name of the boat because of the workshop we were attending. We may find this scientific explanation sufficient and therefore believe that we do not need any symbolic interpretation (which is a metaphysical stand itself). But even if we insist on finding a symbolic interpretation of our observation, of course we may have others than the one I gave. For example:

"Evolution is an obstacle that we should let pass and then continue our journey." Or (one that is not my personal favourite):

"Evolution is a scientific theory that will just pass by and be exchanged for new scientific theories soon."

I do not think there are scientific arguments to find one interpretation better than the other, although there may be other arguments.

Well, I am not the philosopher or theologian, so I am open to any criticism on my interpretation.

$:-)$

I wish you all the best, and want to thank you once again for your presence, wonderful contributions in the form of papers and discussion and interesting personal conversations we have had!

Sincerely,

Duur" 


\section{Literature}

Aanen, D. K., 2013. The dawn of Darwinian Agriculture. Evolution 67, 1231-1233.

Aanen, D. K., Licht, H. H. D., Debets, A. J. M., Kerstes, N. A. G., Hoekstra, R. F., Boomsma, J. J., 2009. High Symbiont Relatedness Stabilizes Mutualistic Cooperation in Fungus-Growing Termites. Science 326, 1103-1106, doi:10.1126/ science.1173462.

Bastiaans, E., Debets, A. J. M., Aanen, D. K., 2015. Experimental demonstration of the benefits of somatic fusion and the consequences for allorecognition. Evolution 69, 1091-1099, doi:10.1111/evo.12626.

Bastiaans, E., Debets, A. J. M., Aanen, D. K., 2016. Experimental evolution reveals that high relatedness protects multicellular cooperation from cheaters. Nature Communications 7, doi:10.1038/ncomms11435.

Darwin, C., 1859. On the Tendency of Species to form Varieties; and on the Perpetuation of Varieties and Species by Natural Means of Selection John Murray Books.

Denison, R. F., 2012. Darwinian Agriculture. How Understanding Evolution can Improve Agriculture. . Princeton University Press, Princeton and Oxford.

Fehr, E., Gachter, S., 2002. Altruistic punishment in humans. Nature 415, 137-140, doi:10.1038/415137a.

Fisher, R. A., 1930. The Genetical Theory of Natural Selection. Clarendon Press, Oxford.

Galton, F., 1898. A diagram of heredity. . Nature 57, 293.

Hamilton, W. D., 1964. Genetical Evolution of Social Behaviour 1. Journal of Theoretical Biology 7, 1-16.

Harari, Y. N., 2014. Sapiens: A Brief History of Humankind. Harvill Secker, London. Harari, Y. N., 2016. Homo Deus: A Brief History of Tomorrow. Harvill Secker, London.

Hardin, G., 1968. Tragedy of the Commons. Science 162, 1243-\&.

Keller, L., 1999. Levels of Selection in Evolution. University Press, Princeton, NJ., Princeton.

Maynard Smith, J., 1988. Science, Ideology and Myth. Did Darwin get it right? Springer.

Mendel, G., 1866. Versuche Über Pflanzen-Hybriden. Verhandlungen des naturforschenden Vereines zu Brünn 4, 3-47.

Muir, W. M., 1996. Group selection for adaptation to multiple-hen cages: Selection program and direct responses. Poultry Science 75, 447-458.

Okasha, S., 2018. Agents and Goals in Evolution. Oxford University Press.

Richerson, P. J., Boyd, R., 2005. Not By Genes Alone: How Culture Transformed Human Evolution. University of Chicago Press, Chicago.

Scott-Phillips, T. C., Dickins, T. E., West, S. A., 2011. Evolutionary Theory and the 
Ultimate-Proximate Distinction in the Human Behavioral Sciences. Perspectives on Psychological Science 6, 38-47, doi:10.1177/1745691610393528.

Swaab, R. I., Schaerer, M., Anicich, E. M., Ronay, R., Galinsky, A. D., 2014. The Too-Much-Talent Effect: Team Interdependence Determines When More Talent Is Too Much or Not Enough. Psychological Science 25, 1581-1591, doi:10.1177/0956797614537280.

Weiner, J., Du, Y. L., Zhang, C., Qin, X. L., Li, F. M., 2017. Evolutionary agroecology: individual fitness and population yield in wheat (Triticum aestivum). Ecology 98, 2261-2266, doi:10.1002/ecy.1934. 



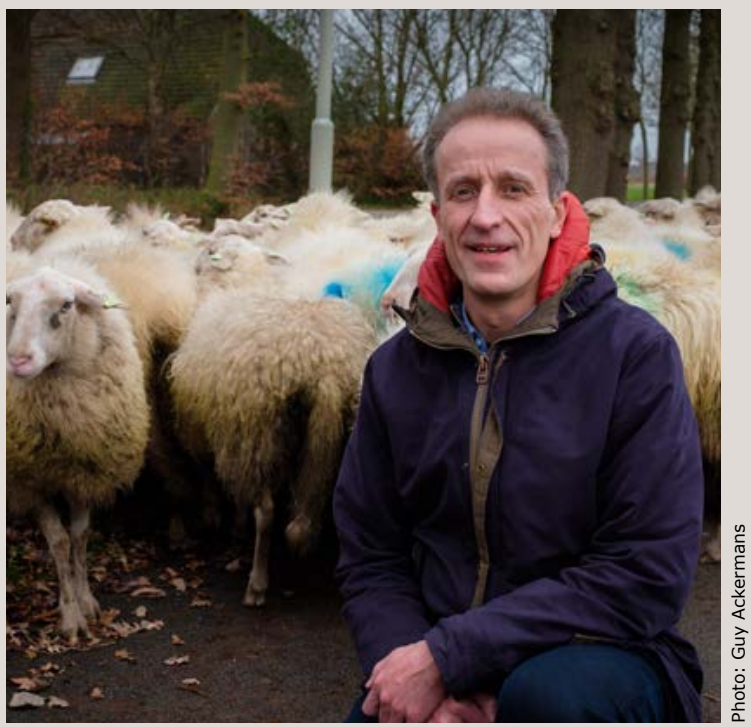

Prof.dr Duur K. Aanen

'Some people consider evolutionary biology a mixture of science and myth, a blending of scientific observation and moral or ideological implications. I ask if the evolution of cooperation is a case in point, focusing on the evolution of human cooperation and considering cultural evolution. I discuss current insights, using examples from our own research, and the history of this research field since Darwin. Is there a basis for the suspicion that evolution is not only science?' 